\title{
PHIMAI SANCTUARY (THAILAND) AND NOSTALGIA IN WORLD HERITAGE
}

\author{
S. Gapphimai ${ }^{1, *}$, S. Weerataweemas ${ }^{1}$ \\ ${ }^{1}$ Faculty of Architecture, Khon Kean University - aomamp_103@yahoo.com
}

Commission II - WG II/8

KEY WORDS: Physical space, World heritage, Phimai sanctuary

\begin{abstract}
:
This article aimed to examine the physical space management of Phimai town related to Phimai Sanctuary with a goal for improv ing of physical aspect that mainly focused on the conservation of the town and archaeological sites. The framework of this study was conducted during 1954-2017 by analysing through the concept of discourse analysis. It was found that a main factor at such time was happened from declaration of the government policy on "Boundary Line of Phimai Archaeological Site" in 2016 and Phimai Sanctuary had ever been in the "Tentative List" of world heritage in 2003. At that time, it was affected to the changing and improvement of the area from 2 main groups of representatives that had their duties to look after and manage that area as; a group from central administration as Fine Arts Department and another group from regional or local administrations. The study came from production of physical space i.e. construction of road networks, public spaces or other compositions. The cultural herit age of Phimai Sanctuary was applied to describe or manage the spaces for conservation and promotion of tourism activities. Those demands were managed by only one group or authorized group of representatives that did not answer or indicate problems of Phimai area development. On the other hand, it was emphasized on the space management without any local participation and effected to current residents in that area directly.
\end{abstract}

\section{INTRODUCTION}

Phimai Sanctuary, located in Phimai Historical Park, Nakhon Ratchasima Province, is regarded as a Hinduism temple and a place of worship in Mahayana Buddhism, has its historical importance for a long time (Walliphodom, 1956). The sanctuary has been located in the northeastern region of Thailand, that is regarded as the biggest and perfect archaeological site under the Khmer culture in this country. From the important of history and archaeology, it makes this archaeological site being a significant tourism resource that earns income and fame for the country.

Later, in 2004 Phimai Sanctuary was placed on the tentative lists under the name of "Phimai, its Cultural Route and the Associated Temples of Phanomrung and Mueangtam" (Unesco.org) for registration as a world heritage site. This has caused many changes of such area in multi levels from state's operations on the space management of Phimai Town for being a national cultural heritage needed to be a world cultural heritage". Placing on the tentative list was not only changing its meaning, but also affecting processes for being a world heritage site. Such operations had their results on space management affecting communities and made crowding and space marginalization with residents and the Fine Arts Department had authority to manage it absolutely.

Fine Arts Department began to manage the Phimai Sanctuary Archaeological Site for its restoration since 1954, that was the first time of archaeological work in Phimai Town. The town reconstruction and development plan was stipulated systematically to maintain and restore this ancient Khmer town affecting traditional folkway that had not any relationship with conservation of archaeological sites. Modification of physical spaces with relationship or non-relationship with conservation was moved out, so the government agencies were the first space that moved out. Those operations have been happened for almost 60 years and gradually increased after placing on the tentative lists.

How such operations happened and effected to communities or created conflicts with residents in the area has never been examined and studied before. This may be a case study for towns where people live together with archaeological sites or be useful for planning to manage towns where people live together with archaeological sites sustainably in the future.

\subsection{Objectives of the Study}

Purpose of this research was to study the management of physical spaces from the processes of the government agencies' power in order to manage the spaces of Phimai archaeological site and Phimai Town by examination of discursive formation for managing the area since 1954 until attempting to nominate Phimai for being the world heritage town.

\subsection{Conceptual Framework and Related Theory}

Conceptual framework of this study was based on physical changes on place/space of Phimai Town caused by a government agency that had its authority for making policies to control or manage archaeological sites such as Fine Arts Department. There were attempts to play its role on making definition of Phimai Sanctuary and the area of ancient Phimai Town by a concept of conservation as archaeological sites that should be conserved. This concept was conducted for long time and the supreme goal of conservation was an attempt to push towards for being certified as a world heritage and to create

\footnotetext{
* Corresponding author
} 
knowledge for controlling definition of the sanctuary for any management or changes of the space, and the discourse of power was always referred to achieve that goal. The thought of Foucault on discourse analysis was used in processes of power practice and discourse construction, he said that discourse was not only a form of a representation of something.

In Foucault's Archaeology of Knowledge, he specified the meaning of knowledge framework as all knowledge set of relationship that had its unity at a period of time. Discursive practice caused transition from studying of epistemology, science and regulations to stipulate and conduct the discourse construction e.g. co (Foucault,1995) observation of Phimai Sanctuary or development of Phimai Town presented by government sector or local organization. This was regarded as a kind of discourse construction by academics that made clear understanding on the determinative meaning of sanctuary as what was the goal and how physical was affected?

The thought of Peleggi in his work entitled "The Politics of Ruins and the Business of Nostalgia", he wrote the introduction of an article "From National Heritage to World Cultural Heritage" by using Thailand as a case study. He suggested that phenomenon of cultural heritages in Thailand occurred more than 2 decades ago and widely extended in form of physical dramatic transformation related to heritage industry, which were formed and grown together. Nostalgia was stimulated in Thailand in middle class with a new aspect of consumption that caused a burst of the cultural tourism business in 1980s. In the meantime, some Thai academics and intellectuals opposed for something that be affected from those operations and would be disappeared (Peleggi, 2002).

\subsection{Research Methodology}

The objectives of this study focused on physical changes of the area by placing value or importance on the Phimai Sanctuary. The town was improved by the government and authorized organizations through discourse production with the goal towards a world cultural heritage. Method used in this study was area survey and Phimai Sanctuary was the centre of the study along with aerial maps as evidences. This showed changes from production of physical space such as road network and transformation of public space. Inspection evidences of project operations, both of operations done by the department or gave budgets for other agencies to operate, such as academic researches to use as referent reasons or discourses in operations were used for analysis of influencing factors on those changes. Each period of the past decades, there were guidelines for making policy of management that might be influenced from both of politic and socio-economic aspect in national or international level. These expressed the exercising of power to guide changing of the Phimai Town, protest or groups of conflict against knowledge framework and discourses affecting physical changes in each period that connected to relationship dimension of the Phimai Sanctuary. Conceptual frameworks were used for analysing of space changes by referring to theories from behaviours of utilization and interaction between people and physical components of the space. These made some suggestion, guidelines for compromising the management of urban space with archaeological sites and for being a sample space on living together between communities and archaeological sites or applying such conceptual framework or theories to other spaces in Thailand.

\section{PHIMAI SANCTUARY FROM SACRED SPACE TO NATIONAL ARCHAEOLOGICAL SITE}

Phimai Stone Sanctuary has been constructed from wisdom, belief and faith of many kings in Dynasty of Mahidharapura, they are regarded as creators of the Great Angkor Wat to be a place for worshiping to Buddha from their faith in Buddhism. There is a study about belief from iconographical evidences that appeared in Phimai Sanctuary with artistic style to indicate its construction about the 16-18th Buddhist Era. After the reign of Jayavarman VII, the last king of Ancient Khmer Kingdom, Phimai Town and Phimai Stone Sanctuary were abandoned since the 18th Buddhist Era. In the late Ayutthaya period while the kingdom was destroying by the Burmese troops, at that time Krom Muen Thepphiphit, a royal family, escaped from the capital to gather troops at Nakhon Ratchasima and Phimai town. A Buddhist temple was constructed in the inner area of Phimai Sanctuary, as ancient ponds shown around the main stupa of Phimai Sanctuary, but after that Phimai Sanctuary was abandoned once again (Fine Arts Department, 1989).

In the time of colonialism at the 24th Buddhist Era, Phimai Sanctuary was granted meaning as an important archaeological site of Siam from the king and royal family of Siam that placed importance on all archaeological sites throughout the kingdom. Phimai Sanctuary was an archaeological site that recorded and begun to continually develop the conceptual framework of archaeological site conservation from western i.e. Ecole Française d'Extreme-Orient. After that, the Fine Arts Department was established as the main government agency to look after archaeological sites and antiques.

The significant beginning for archaeological site conservation all around the country. In the level of southeast Asian region, placing importance on archaeological site restoration was lively occurred and successfulness on restoration by Anastylosis technique was clearly happened at Angkor Wat in Cambodia. Remains and piles of stone were left for hundreds of years were rearranged and enhanced landscape to make the great image of Angkor Wat return to be real again. Restoration at Angkor Wat was very succeeded due to surrounded area of Angkor Wat had neither communities nor residents, therefore, guidelines for management were arisen rapidly without any obstacles. This influenced to great conservation and restoration throughout regions of Thailand included Phimai Sanctuary. The restoration of Phimai Sanctuary was an assistance from French government to Thai government by sending an expert of Angkor Wat Restoration named Mr. Bernard-Philippe Groslier to do his duty as the Project Manager, an archaeologist named Mr. Pfeiffer and Mr. Pierre Pichard collaboratively restore the Phimai Sanctuary.

The restoration of Phimai Sanctuary was conducted by pulling the main stupa down, digging soil for making new foundation, reinforcing structure with concrete for its durability, rearranging stones back to original form and finally the ruined sanctuary was perfected (Pichard, 1976), this was the same technique as Angkor Wat restoration. In 1962, plans were prepared and submitted to the cabinet at that time, it was the beginning of archaeological work firstly in Phimai town. The restoration plan for Phimai Sanctuary was specified step by step systematically by determination of a goal to make "Phimai town have its conditions as same as traditional ancient town". State power was used for moving non-original components out of the Phimai town and this plan was regarded as the most correct method for conservation. The plan was conducted by expropriation and moving civilian residences, temples, schools, government offices more than 1,000 households on total area about 328 Rai (52.48 ha) out of 
the downtown in accordance with 4-year action plan (National Achieves of Thailand) that got along with the sanctuary restoration. At that time Thailand adopted international conservation legally by membership of United Nations Educational, Scientific and Cultural Organization (UNESCO), a specialized agent in aspect of science and culture on January 1 , 1949 (Chungsiriarak, 2015).

This made Fine Arts Department obtain rights and full authority on management of this area that had a project for restoration of Phimai Sanctuary and Phimai Town in 1962. There was an idea for the establishment of museum to collect antiques found in the area of Phimai town or adjacent areas, to store and look after with security system as well as having demand to extend the boundary line of Phimai Archaeological Site over the ancient town and planed entire operations for 4 years and spent budget about THB 70,000,000 (National Achieves of Thailand, 1962).

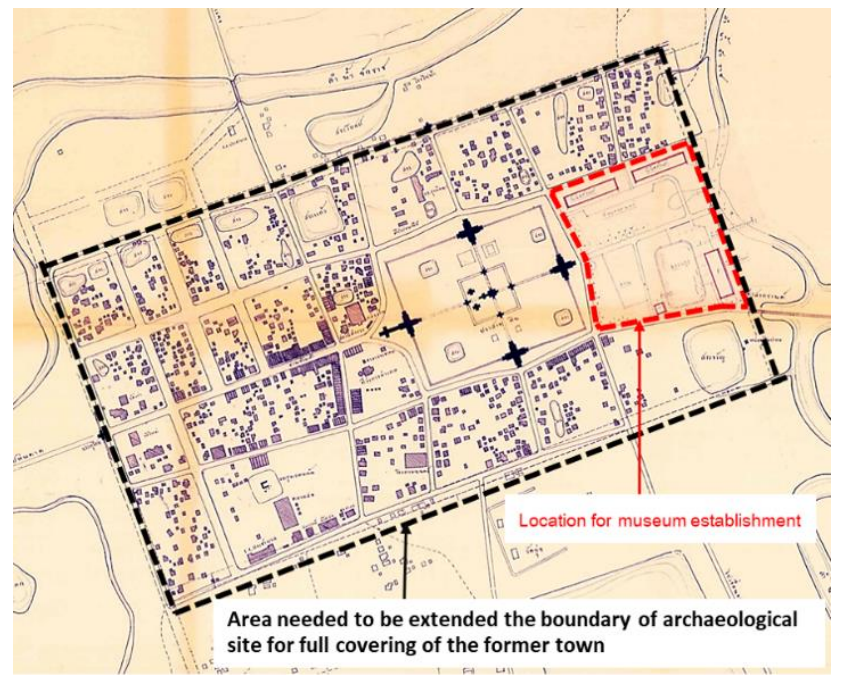

Figure 1. Phimai Archaeological Site over the ancient town and planed. Source: Fine Arts Department.

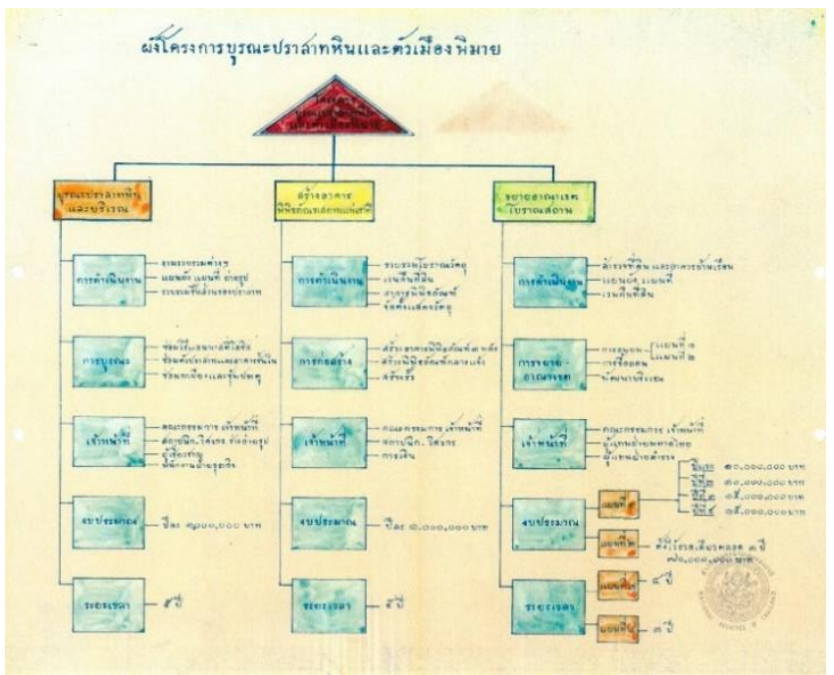

Figure 2. Flow Chart of Phimai Town Restoration Project 1962. Source: Fine Arts Department.

However, such plan was unsuccessful because the government at that time was encountered with financial problems and threatened by domestic communism. It could not expropriate and establish the museum but could extend the boundary line of archaeological site only at the front of sanctuary. The project of "Phimai town have its conditions as same as traditional ancient town" was regarded as a discursive practice of archaeological site occurred on the Phimai Town. From his thought on the occurrence of discourse (Foucault, 1981), any set of discourse shall have its system to prevent other discourses by suppressing, dividing and refusing of other discourses that had the same topic e.g. a mainstream of archaeological site discourse that controlled the meaning of ancient buildings by stipulating of a new terminology as "Archaeological Site".

The determination of academic value was studied as an understandable evidence from the past by specific method of experts, who reviewed the correct guidelines instead of former meaning of discourse. Most of local people frequently clung to value of ancient buildings as sacred places, religious buildings of current people were connected with the past by stories that had been told continually in many forms. It could be seen that concept of conservation was to reconstruct an ancient Khmer town by separating people out of the area was already happened. Restoration of Phimai Sanctuary was continually conducted by Fine Arts Department as the main agency.

\section{PHIMAI SANCTUARY AND OPERATIONS TO BE WORLD CULTURAL HERITAGE}

Phimai Historical Park was established in 1989. Before the establishment of Phimai Historical Park, a plan for conservation and promotion on arts and cultural study in form of a historical park was prepared by Fine Arts Department in 1976 (Fine Arts Department, 1989). One of the preparations for historical park establishment was modification the physical area of the town to support tourism activities or spaces affecting archaeological site conservation. This physical change was moving bus terminal and municipal market out of former space to bypass road at the west of sanctuary in 1989.

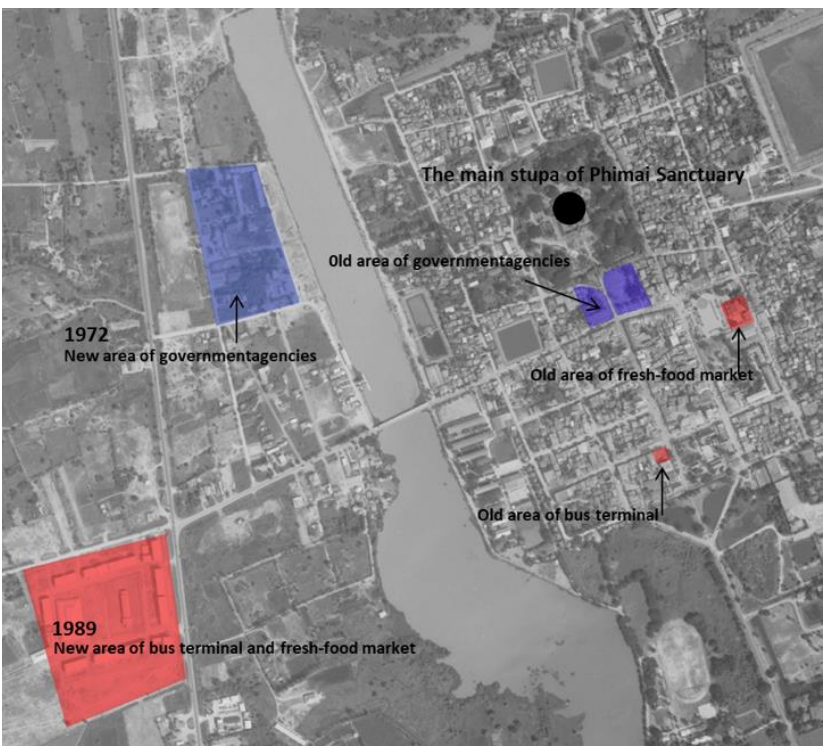

Figure 3. Physical space of Phimai Town in 1989. Modified from an aerial map.

The western area of Phimai town become the government centre and commercial centre of the new town. Praicharnjit studied about archaeological resources management and found that during 1973-1974 the executives of Fine Arts Department adopted a concept for applying archaeological site to earn income for the country from tourism. Thus, important archaeological 
sites should be looked after particularly by establishment of historical parks and the first one was begun at the ancient town of Sukhothai in 1975 (Praicharnjit, 2007).

For Phimai Sanctuary, the conceptual framework for developing as a tourist attraction, in accordance with mainstream of country and global development, was used by Fine Arts Department to be a reference for operating the Project on Space Development of Phimai Town once again. Placing importance on tourism made Fine Arts Department issued distinct rules and practice guidelines for visiting the sanctuary, this discourse on visiting of archaeological sites was referred to control all activities in the area. However, the Fine Arts Department could only offer to move bus terminal and municipal market out of the town wall zone, whereas villages in community were limited to enter into the sanctuary wall.

The knowledge of history - archaeology, that the Fine Arts Department established by using state power, was a part on changing the meaning of Phimai Sanctuary according to the folk legend of "Thao Pajit and Orapim"1 Knowledge set of history archaeology played its role on controlling activities of community that ever used the sanctuary space, relationship between community and the sanctuary was obstructed by entire management of Fine Arts Department and old memories were faded out. The sacred place in conform with folk legend was replaced by the biggest ancient Khmer archaeological site of Thailand.

\section{RESULT AND DISCUSSION}

\subsection{Attempt to Push Phimai forward to be World Heritage Town}

Under the stream on pushing forward of cultural heritage, it was highly succeeded of being the world heritage since 1987, many sources of cultural heritage in Southeast Asia Region were registered as world cultural heritage e.g. Ayutthaya Historical City, Sukhothai Historical Town and Associated Towns in 1991, Angkor Wat World Heritage Site at Cambodia in 1992, Borobudur Temple Compounds at Indonesia in 1991 or Luang Phrabang World Cultural Heritage Town at Laos in 1995 (unesco.org). Income from tourism of Thailand during 10 years from 1980 to 1990 had increased up to 93,000 million Bahts, this made the government supported tourism associated with archaeological site development (Peleggi, 2002).

Peleggi presented two parts of his thought. Firstly, "The Politics of Ruins" looked through the establishment of community's cultural heritage towards national cultural heritage by technique on construction of national history. The establishment of Fine Arts Department for looking after historical sources along with creating of national symbol or identity from local cultural heritages that established as the national cultural heritages. Secondly, he presented the concept of "The Business of Nostalgia"; the main image of this part was analysis of processes that enabled culture become product and tourists' consumption

1 Thao Pajit and Orapim - In the southern part of northeastern region, there is a well-known legend named "Thao Pajit-Orapim" and also a source of places' name e.g. Nang Rong, Phimai, Thung Kraten, Lam Plai Mat and etc. that are used until now. There are many versions with different and same details, but the main story is as follows; Thao Pajit was a Khmer prince from Angkor Thom. He met a pregnant lady in the current territory of Thailand, who had characteristics as predicted as the mother of his soulmate. Thao Pajit, then, asked to live with her until Orapim was born and looked after her. After Thao Pajit returned his town for preparing a marriage proposal. Thao Brahmathat on cultural heritage places. However, relationship between records of state officers in historical section and their presentation about national stories in the past for attracting tourists were conducted on both parts simultaneously. It made national cultural heritages and management for such consumption be concrete.

Besides conservation to maintain archaeological sites as evidences of the past for experts to study, Fine Arts Department also met requirements of people by setting a goal of archaeological site conservation for being a tourist attraction (Fine Arts Department, 1979). Stream of expansion on tourism affecting the study of Phimai town area that turned its interest to tourism issue was differed from the first phase of study on archaeological heritage conservation. Then, it was extended to the town level that focused on environmental conservation to manage spaces and to promote the conservation mainly on the town and archaeological sites, for example, in 1997 Tourism Authority of Thailand granted a large number of budget for studying source of tourist attractions e.g. the project for tourist attraction development of ancient Khmer archaeological site (Planning Division, Tourism Authority of Thailand, 1997) or tourism development project in Nakhon Ratchasima province and adjacent areas (Kasetsart University, 1997), Project for Preparation of Master Plan of Conservation and Development of Ancient Communities in North-eastern Region in 1996 (Faculty of Architecture, Chulalongkorn University, 1996), or A Study of Research Project on Phimai Historical Town for Conservation and Management of Cultural Heritage in 1999 (World Heritage Company Limited, 1995). Both studies offered a guideline for managing and developing the Phimai town that focused on physical area management to promote tourism and conservation groups of archaeological sites.

Discourse that was referred to move towards being a world heritage of Phimai town was a new set of knowledge or goal of government agency for operations in the area of Phimai town. Attempt of Fine Arts Department on possession of entire space in the area of town wall zone by using the word of "World Heritage" as a reason to stipulate a new and wide extended boundary line of archaeological site.

Nomination of Phimai town for a world cultural heritage together with Phanomrung and Mueangtam Sanctuary ${ }^{2}$ might be came from preparedness of the Phimai Sanctuary that was generally accepted but had some conflicts with communities. On the other hand, Phanomrung and Mueangtam Sanctuary were archaeological sites without any big communities and had no problems of overlapping and management compared to the Phimai Sanctuary.

However, preparation of supporting documents for nomination to be a world cultural heritage by referring from "Operational Guidelines for the Implementation of the World Heritage Convention" that had 9 parts of its content used for this study were: "Conservation Status and Factors Affecting Sources" and "Protection and Management" (UNESCO, 2017). Therefore,

sent troops to arrest Orapim and brought her to Phimai, Thao Pajit helped Orapim to escape, but unfortunately there were separated. p.79 (Narasaj, 2014)

2 "Phimai, its Cultural Route and the Associated Temples of Phanomrung and Mueangtam" was a presentation in form of "Serial Nomination". It was a guideline for promoting archaeological sites to have higher potentiality, because presentation of share values of multi sites would have more weight than single one (Kerdsiri, 2016, p.54). 
Phimai Sanctuary together with Phanomrung and Mueangtam Sanctuary were nominated on the tentative list for world heritage registration. Hence, being a world heritage town cited by Fine Arts Department was the main discourse for physical improvement of the Phimai town, not only for being tourist attraction or national heritage as before.

In 2009, Fine Arts Department employed a consulting firm to study "Project for Preparation of Master Plan of Conservation and Development of Phimai Historical Park". This study was a complete report submitted to the 12th Regional Office of Fine Arts at that time. Details of the project mentioned goals of the study linked with requirement for being a world cultural heritage of Phimai Sanctuary by stipulating of significant action plans in aspect of archaeology, history and archaeological site. Plan for improving and developing of landscape as well as plan for developing and tourism services were coming from the concept of "Operational Guidelines for the Implementation of the World Heritage Convention" by World Heritage Committee was applied.

There was attempt on restoration components of ancient town from Angkor Period, such as dredging up a Baray (big reservoir) for having original conditions of water resource, and this caused an idea of expropriation ${ }^{3}$.

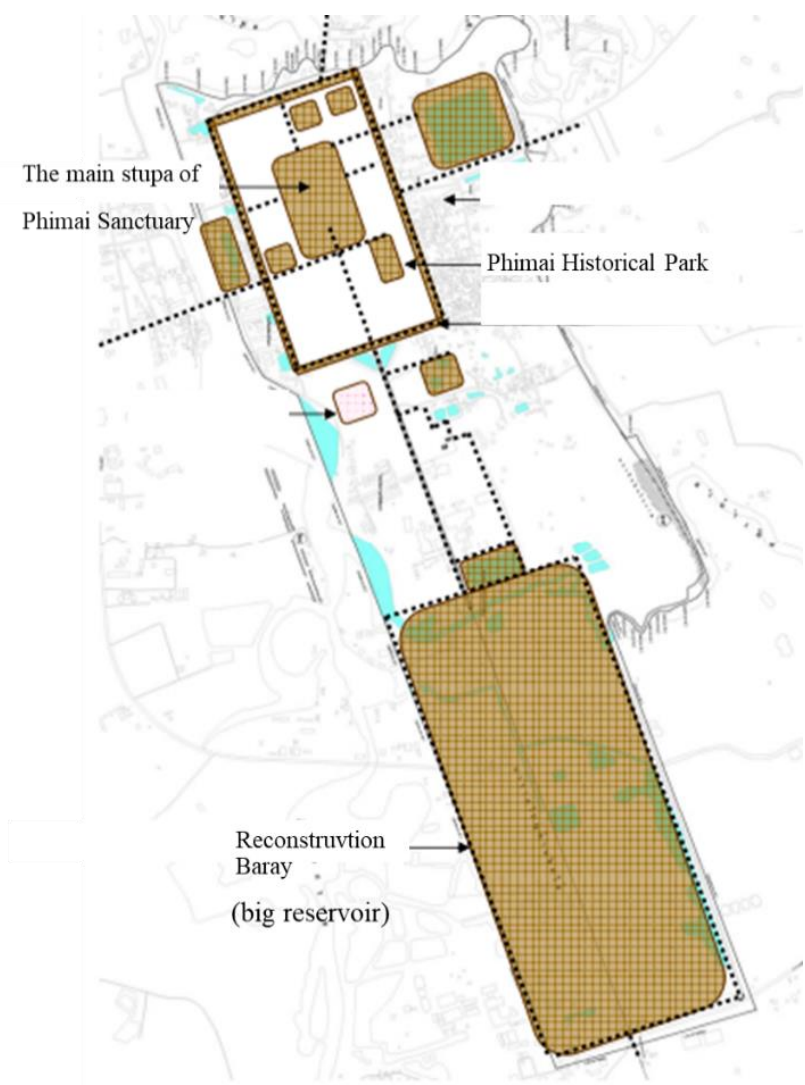

Figure 4. Concept for restoration of Phimai ancient town from "Project for Preparation of Master Plan of Conservation and Development of Phimai Historical Park"

3 This phenomenon was happened with other archaeological sites in the adjacent area. In a document of Fine Arts Department 2005 mentioned that there was a master plan of Phanomrung town operated by a consulting firm on behalf of Fine Arts Department, it was used as a supporting document for world heritage registration. The boundary line of Phanomrung town was settled by this master plan to cover all

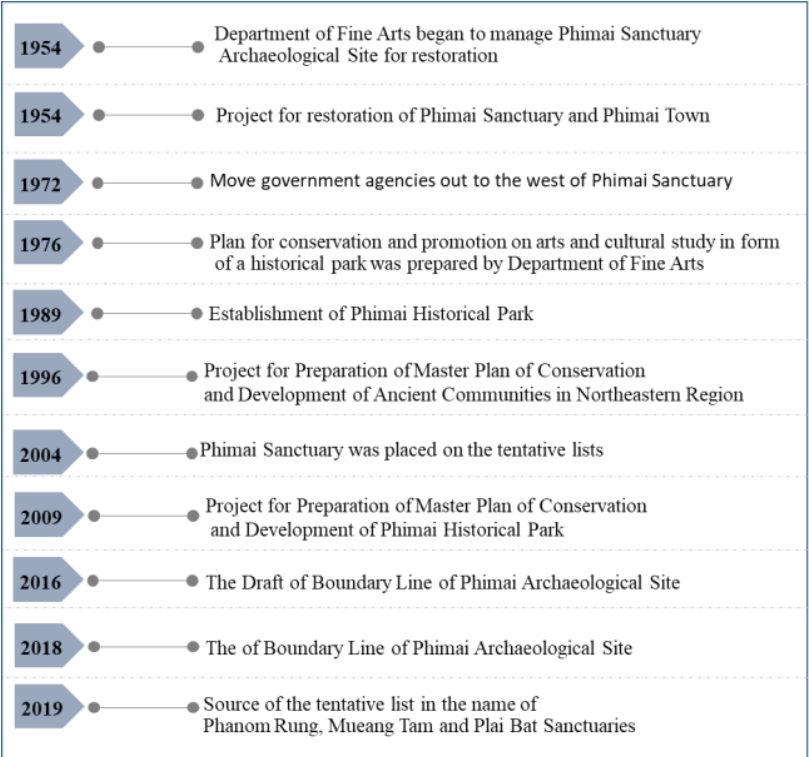

Figure 5. Timeline sheet for phenomenon in Phimai district.

"Project for Preparation of Master Plan of Conservation and Development of Phimai Historical Park 2009" specified a plan for expropriate the area in front of Phimai Sanctuary to improve as a public space for supporting people and tourists as well as a plan for landscape improvement at Meru Brahmathat area as a court for supporting tourists and other activities. Furthermore, a plan to revive ancient road was conducted by expanding space, designing landscape and growing trees for beautiful scenery; colours and materials similar to the sanctuary were used as specified in this action plan.

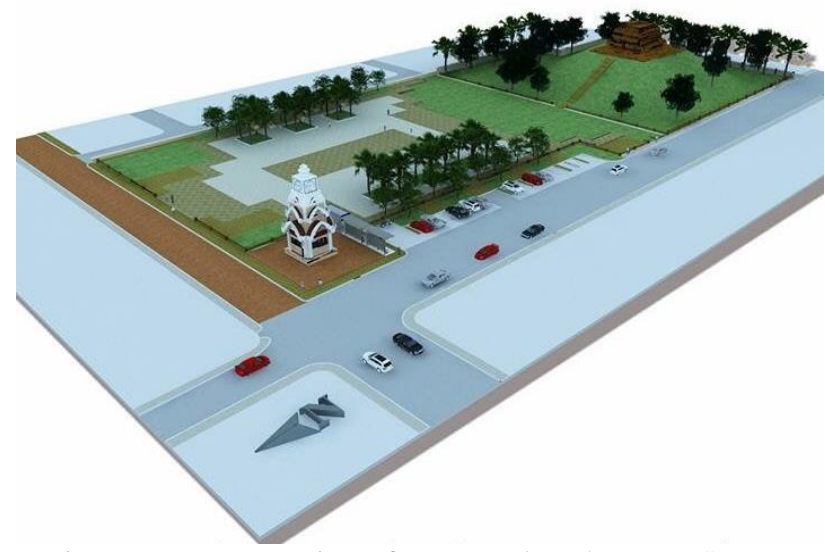

Figure 6. Panorama view of Meru Brahmathat area. Source: Fine Arts Department

Until 2016 the Fine Arts Department announced the draft of boundary line of Phimai Archaeological Site and the 12th Regional Office of Fine Arts sent notice to all people who were in overlapping territorial claims area with the boundary line of archaeological site.

archaeological sites in Chorakhemak District included Bua Rai Village, Buriram Province, for being the zone of archaeological sites and buffer zone between archaeological site and communities (Fine Arts Department, 2005). 


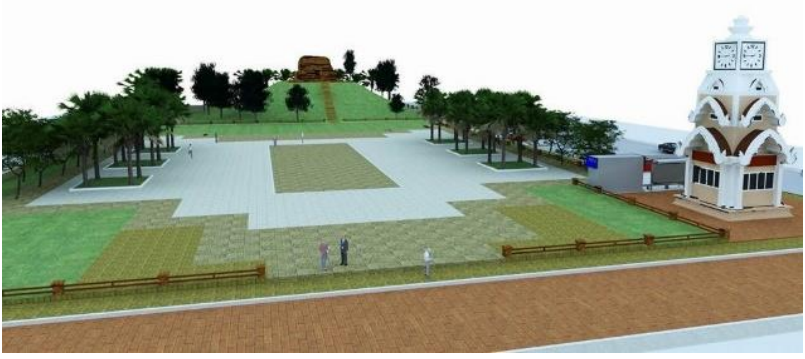

Figure.7. Panorama view of Meru Brahmathat area - Source: Fine Arts Department

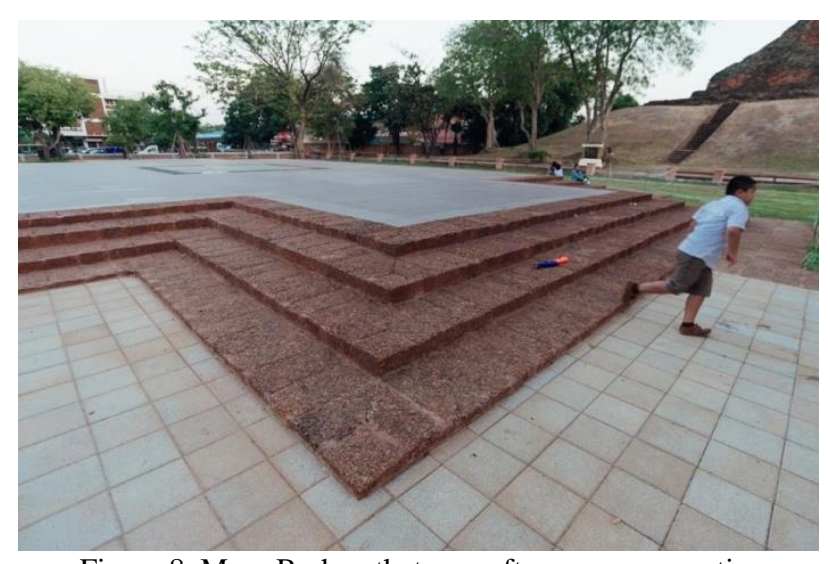

Figure 8. Meru Brahmathat area after space renovation

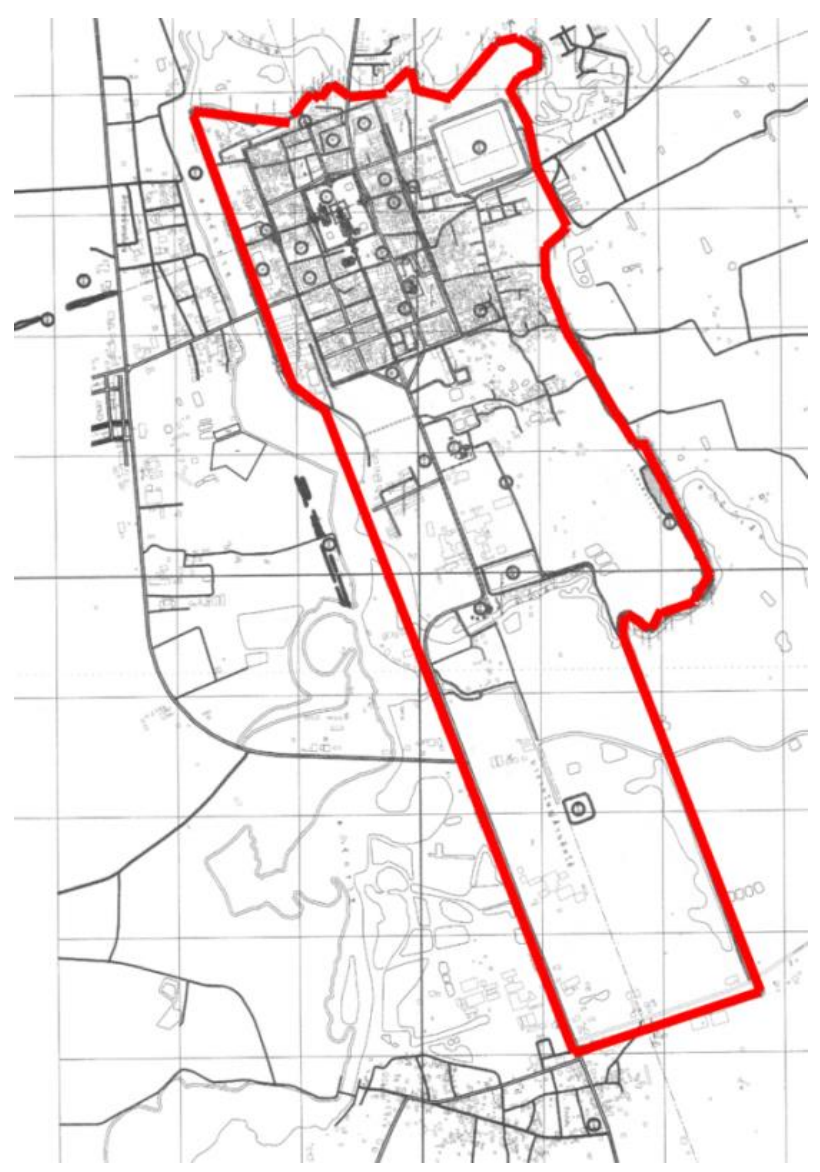

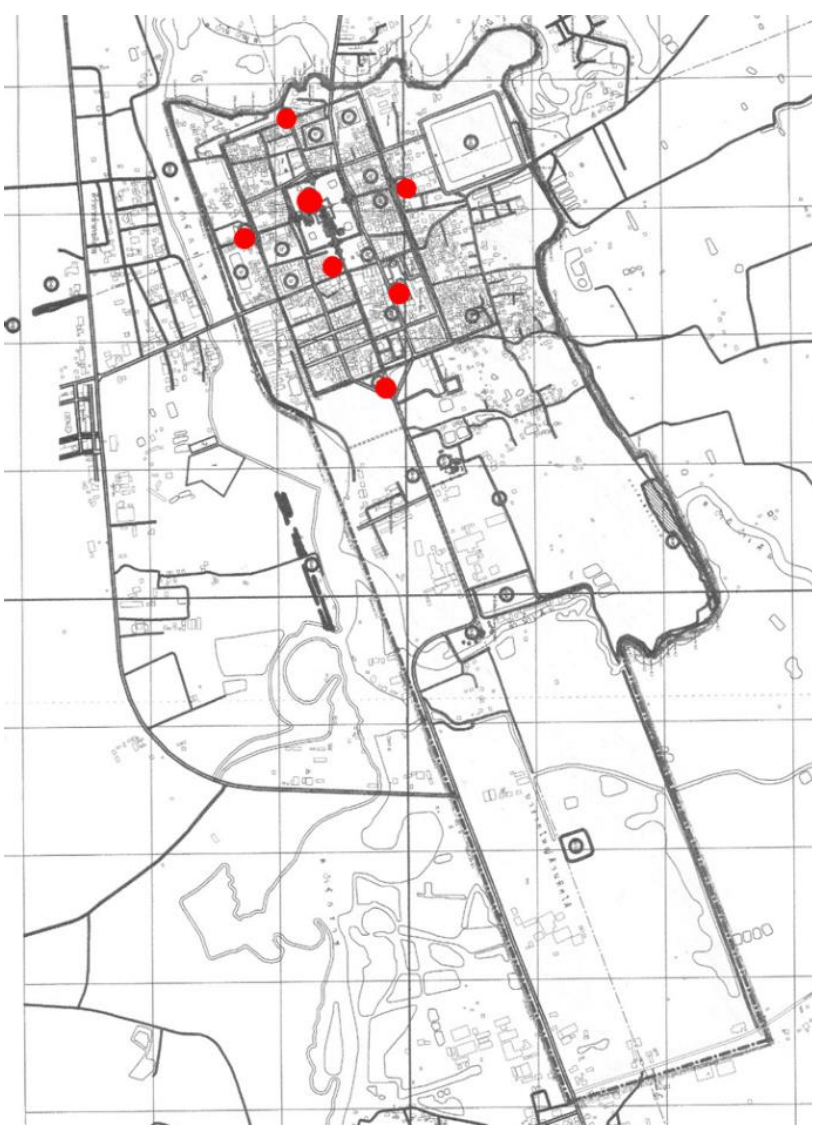

Figure 10. The boundary line of archaeological site declared in 1936.

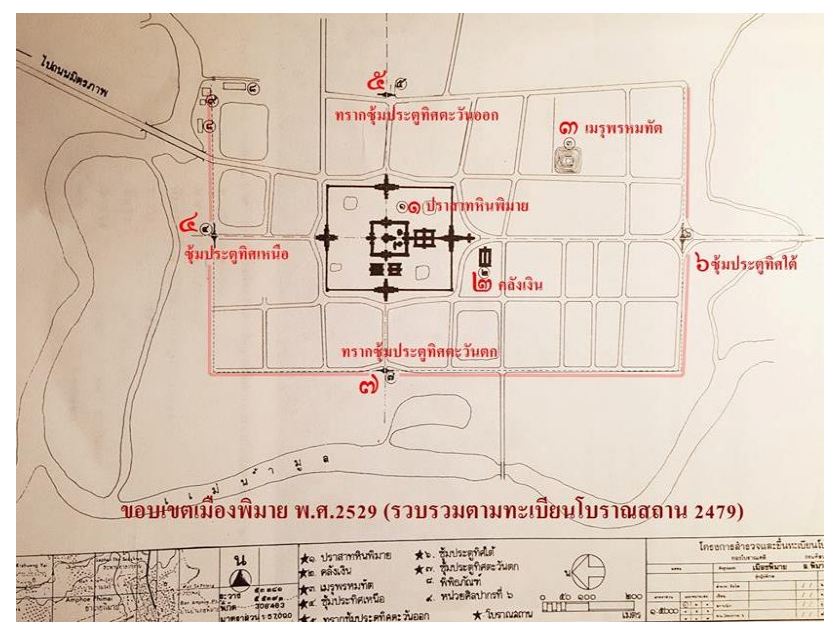

Figure 11. The boundary line of archaeological site declared in 1936. Source: Fine Arts Department

It has been seen that it is different from the former boundary line of archaeological site declared by Fine Arts Department which is covered the perimeter of archaeological site only buildings and some part of it, but the new boundary line of archaeological site declared by Fine Arts Department covered all of communities in the wall zone of Phimai town. This enforcement of state power by Fine Arts Department makes conflict with communities and they protested against the draft of declaration as mentioned above.

Figure. 9. The boundary line of archaeological site declared in 2016 


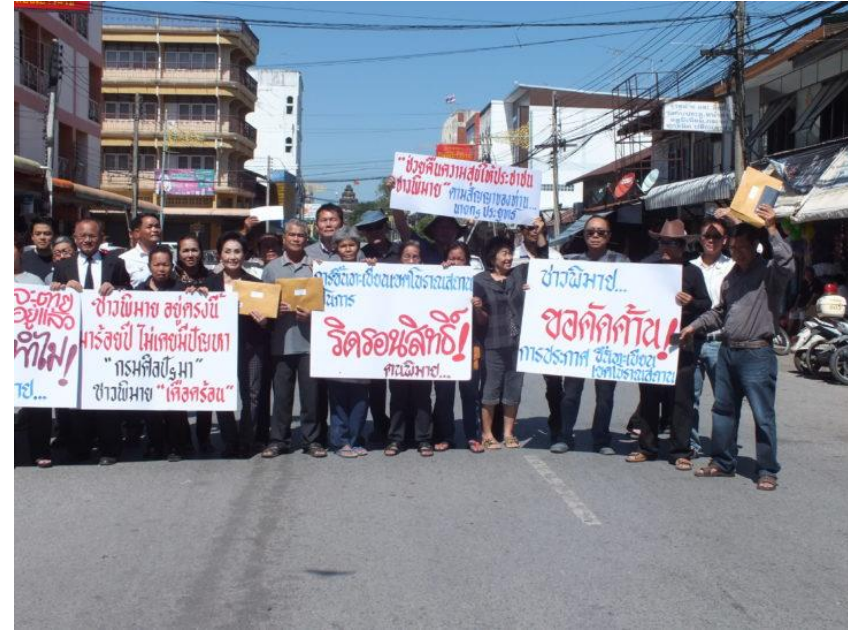

Figure 12. Picketing by people to protest against the draft of boundary line of archaeological site declared in 2016. Source: Matichon online

Conflict problems are caused by the new boundary line of archaeological site that cover the entire are of the tow. It is not only conflict with communities, but also with a local administrative organization, Phimai Subdistrict Municipality, the authority of Fine Arts Department is overlapped with the authority on area management of the municipality.

\section{CONCLUSION}

The Fine Arts Department was assigned to control and to look after Phimai Archaeological Site at the early of the 16th Buddhist Era and the department had provided the guidelines for restoration of Phimai ancient town at the beginning. It was indicated that Fine Arts Department tried to revive the ancient town of Phimai back to conditions of Angkor Period. Former space of the archaeological site was disturbed by components of current town, referring of national heritage at the beginning showed its attempt to move physical components out of the ancient town. At the high level of tourism, government agencies used it to present projects through discourse of tourism promotion, bus terminal and municipal marker were moved out successfully. Such attempt showed its clarity when the draft of new boundary line of archaeological site was declared by Fine Arts Department to cover the entire town and this caused conflicts with local communities.

The nostalgia of ancient town without components that disturbed significant spaces caused the government agencies did not given the priority to people or contemporary life in the ancient town. These conflicts ought to be an important part that made the project for pushing Phimai town towards world heritage out of tentative list included the sanctuary of Phanomrung and Mueangtam. This was opening a chance for both sanctuaries, with more preparedness in accordance with conceptual framework of world heritage, to pass consideration and be certified as a world heritage.

The conservation of ancient town was overlapped with contemporary life of Phimai town that needed to be find a way out or compromise community's way of life, as a part of the ancient town that supported each other, and showed a sustainable management for maintaining this archaeological site to be in framework of world heritage.
The non-cooperation between government and local was caused the failure of being world heritage of Phimai town. Therefore, Fine Arts Department shall learn this lesson and improve further operational processes in the future.

This article submitted in partial fulfillment of the requirements for the degree of doctor in architecture, Faculty of Architecture, Khon Kean University, Thailand.

\section{REFERENCES}

Chulalongkorn University, 1996. Faculty of Architecture. Bangkok, Chulalongkorn University Press.

Chungsiriarak, S., 2015. Background Concept Theory and Operation of Archaeological Sites Conservation. Bangkok, Silpakorn University Press.

Fine Arts Department, 2005. Master Plan of Conservation and Development of Phanomrung. Bangkok, Fine Arts Department Press.

Fine Arts Department, 1962. National Archives Restoration of Archaeological Site and Phimai Stone Sanctuary. Bangkok, Fine Arts Department Press.

Fine Arts Department, 1989. Phimai Historical Park Archaeology Division. Bangkok, Fine Arts Department Press.

Fine Arts Department, 1997. Development of Tourist Attractions in Physical aspect of Ancient Khmer Archaeological Site: A Case Study of Phimai Stone Sanctuary, - Vol. 10. Bangkok, Fine Arts Department Press.

Fine Arts Department, 1979. Project and Report on Survey and Excavation of Archaeological Sites in North-eastern Region, Vol. the 2th edition. Bangkok, Fine Arts Department Press.

Foucault, M., 1995. Discipline and punish: the birth of the prison. 2nd.ed. New York, Vintage Books Press.

Foucault, M., 1981. The order of discourse. Yong, Robort (ed) Untying the text: a post-structuralist. New York.

Kasetsart University, 1997. Faculty of The Master Plan of Tourism Development, Nakhon Ratchasima Province and Adjacent Areas Vol. Economics and Business Administration. Bangkok, Kasetsart University Press.

Kirdsiri, K., 2016. Status assessment of site in Thailand on the World Heritage Tentative List: Prospects of being placed on the World Heritage List, Department of Architecture, Faculty of Architecture. Bangkok, NAJUA Journal Vol.30

Narasaj, B., 2014. Contested Discourses of Cultural Heritage Management in The Case Phanom Rung Sanctuary. Thammasart University. Bangkok, Thammasat University Press.

National Archives ,1962. Restoration of Archaeological Site and Phimai Stone Sanctuary. Bangkok, Department of Fine Arts Press.

Peleggi, M., 2002.The politics of ruins and the business of nostalgia. Bangkok, White lotus. 
The International Archives of the Photogrammetry, Remote Sensing and Spatial Information Sciences, Volume XLIV-M-1-2020, 2020

HERITAGE2020 (3DPast | RISK-Terra) International Conference, 9-12 September 2020, Valencia, Spain

Pichard, P., 1976. Pimay Etude Architecturale Du Temple. Paris: Ecole Francaise d'Extreme-Orient.

Picketing by people to protest against the draft of boundary line of archaeological site declared in 2016.

https://www.matichon.co.th/education/news_859088/attachment/

Praicharnjit, S., 2007. Management of Archaeological Resources in Community Works. Bangkok, Department of Fine Arts Press.

UNESCO World Heritage Center, 2019.Ensemble of Phanom Rung, Muang Tam and Plai Bat Sanctuaries.

https://www.whc.unesco.org/en/tentativelists/6401/

NESCO World Heritage Center, 2004. Phimai, its Cultural Route and the Associated Temples of Phanomrung and Mueangtam.

https://whc.unesco.org/en/tentativelists/1919/

Walliphodom, M.,1959. Guide to Phimai and Archaeological Sites in Nakhon Ratchasima Province. Bangkok, Department of Fine Arts Press.

World Heritage Company Limited, 1995. A Study on the Environment of Phimai Town and Planning of Conservation and Development. Bangkok, Petai Printing. 